\title{
ESTUDIOS
}

\section{Vicente Huidobro: Comienzos de una vocación poética}

$\mathbf{H}^{\mathrm{L}}$ cauterio, dice Larousse, "tiene por objeto atraer al exterior una inflamación que podría atacar un órgano profundo". El cauterio de la verdad es preciso aplicarlo a la leyenda que creó en vida el desaparecido poeta chileno Vicente Huidobro, para sacar luego a la luz el valor profundo de su poesía. Ningún poeta de su generación ha sido menos comprendido que el autor de Altazor, y esto se debe, sólo en parte, al carácter llamado hermético de su obra.

Sería inútil dejar de reconocer que la personalidad del poeta dió lugar a una serie de escándalos y polémicas que han llamado la atención del público más hacia el hombre que hacia la poesía. El propósito de este trabajo no es el de rememorar viejos chismes. Se trata de aclarar los motivos de la enemistad de la que fué objeto Huidobro, y de mostrar que a la larga los incidentes mencionados nada tienen que ver con el valor de la obra, aunque sí mucho con ciertas obsesiones que determinan la posición del poeta con respecto a la creación poética. Para juzgar bien algunas de estas polémicas será preciso, en la segunda parte de este artículo, dedicarnos al eștudio de las abras juveniles publicadas en Chile. 
No hay mejor manera de empezar un bosquejo de la personalidad de Vicente Huidobro que con el juicio equilibrado de Gerardo Diego, amigo y discípulo que fué de Huidobro. El poeta y académico español escribe en 1948:

Era Vicente Huidobro, cuando yo le conoci, hace treinta años, un muchacho lleno de vida, dé ímpetu juvenil, de simpática petulancia y simpatía abierta y generosa. Era, aparte sus virtudes de artista, un amigo leal, óptimo y optimista. Sus terribles pasiones y sus pueriles vanidades quedaban olvidadas ante el espectáculo pintoresco que la vida le deparaba al pasear del brazo de cualquier amigo de buena fe.1

Estas "terribles pasiones" y "pueriles vanidades" que se siente obligado a mencionar Gerardo Diego, están vinculadas todas con el deseo obsesivo que tenía Huidobro, no sólo de ser iniciador en materia de poesía, sino de presentarse como tal ante el público. Al servicio de este último objeto, fruto de una funesta confusión entre causa y efecto, ejercía Huidobro sus talentos histriónicos en la creación de situaciones que resultaban perjudiciales para la justa apreciación de sus talentos poéticos.

En el concepto de Huidobro, el poeta debía ser un personaje de poderes y atributos divinos. Resumió su doctrina en el conocido verso "el poeta es un pequeño Dios".2 Aunque se refiere aquí a la idea de que el poeta reina solo en el mundo independiente de sus creaciones, el poema Altazor está ahí para probar que en la obra de su madurez soñaba con darle a esta frase un significado literal. ${ }^{3}$

Desde muy joven hizo suya la idea romántica del poeta como héroe, como campeón solitario del ideal; y llega más

1 Gerardo Diego, Vicente Huidobro (Madrid, 1948), pág. 7. (Tirada aparte de la Revista de Indias, 33-34, julio-diciembre de 1948, págs. 1173-1180).

2 Del poema "Arte poético", de El Espejo de agua, segunda edición (Madrid, 1918). Para otros libros de Huidobro véase la lista de libros de Huidobro consul tados para este trabajo.

3 Hablaremos de este punto en un trabajo que preparamos titulado "Ia muerte de Altazor". 
tarde a identificar al poeta, víctima expiatoria, con el Cristo doliente.4 Este concepto del poeta aparece por primera vez en los versos juveniles reunidos en el libro Ecos del alma. "La muerte del poeta" comienza con el verso "Murióse el bardo, el de la lira de oro", y continúa en los siguientes términos :
Murióse abandonado en su cabaña
porque el mundo jamás lo comprendió.
Llamóle loco y en su fiera saña
sus ideales por tierra le arrojó...
Mueren con él su nombre y sus ideales, los aplausos se olvidan que ganó, se marchitan los lauros inmortales que su frente gloriosa un tiempo vió.

El prólogo de Ecos del alma, redactado, como de costumbre, por un íntimo amigo del autor, no vacila en dar esta receta para un buen poeta: "Hay en su alma un inquieto Quijote ... siempre dispuesto a embestir contra los molinos de viento y ciegamente enamorado de la perfección y de la belleza..." El poeta, figura solitaria, vive aislado, "como las fieras en sus cavernas... Se siente en todas partes extraño. No encuentra donde plantar su tienda."

Fué éste el papel que se propuso hacer Huidobro. Más tarde escribe a este respecto:

En mis primeros años toda mi vida artística se resume en una escala de ambiciones. A los diez y siete años me dije: debo ser el primer poeta de América; luego al pasar de los años pensé: debo ser el primer poeta de mi lengua. Despuês a medida que corría el tiempo, mis ambiciones fueron subiendo y me dije: es preciso ser el primer poeta de mi siglo.5

Para lograr esta ambición contaba el joven poeta con el apoyo entusiasta de su madre, pues a la señora María Luisa Fernández de Huidobro le daba también por escribir. Corrigió los primeros versos de su hijo, escritos a los doce años y bautizados con el título característico de "Eso soy yo".6 La

* Manifestes, págs. 101-103.

5 Vientos contrarios, pág. 35.

6 Pasando y pasando, pág. 25. 
madre le proporcionó los medios necesarios para hacer el papel escogido: Huidobro pudo publicar sus libros juveniles, quizá con excesiva facilidad; fundó dos revistas literarias antes de llegar a los veintiún años ; 7 tenía facilidades envidiables para agasajar a los amigos. Estos, a su vez, se apresuraban a halagarlo como jefe y Mecenas. Comentó uno de ellos :

...no puedo pasar por alto la decidida dilección que él guarda por los artistas chilenos, y lamento en esta ocasión no poseer la flórida fluidez de una Sevigné para espiritualizar una crónica de esas sus íntimas reuniones intelectuales. . 8

Ya hemos dicho que para Huidobro el poeta debía ser una especie de mártir a manos del vulgo. Según el artículo autobiográfico "Yo", que se encuentra en el libro de ensayos Pasando y pasando, publicado en 1914, cuando el autor no llegaba aún a los veintiún años, Huidobro se había iniciado en este papel en el colegio de jesuitas, donde hizo sus estudios. Acusado de haber hecho propaganda entre sus condiscípulos a favor de las novelas de Zola, se disculpa Huidobro diciendo que no ha hecho más que mencionar un artículo sobre Zola a algún amigo. Cuando el rector, incrédulo, le alega lo de "río que suena, lleva piedras", el joven le responde: "Es el único refrán que no puede estar en labios de un jesuita, porque desde que se fundó la Compañía de Jesús hasta el día de hoy se habla mal de ella". Y sale del colegio para no volver (pág. 19).

Situaciones de este tipo ocurren con frecuencia en la vida del poeta. Acusado "injustamente", contesta con un ataque personal y se crea un enemigo más, casi como si buscara deliberadamente el "martirio". Tal parece ser el sentido de esta observación, que citamos del mismo artículo: "En mi corta vida ljteraria he sido muy querido y muy odiado. Puede darse mayor triunfo?" Muy aficionado a la política literaria, sigue diciendo, sin ocultar el placer que le ocasiona el tema:

7 Pasando y pasando, pág. 29. Las revistas se llaman Musa joven y Azul.

8 Juan Rojas Segovia, fragmento sin título incluido en Huidobro, Canciones en la nocbe, pág. 90. 
He tenido enemigos que se han dado el trabajo, alentados por la envidia, de ir a desacreditarme ante muchos pobres inocentes. Generalmente les ha salido mal el juego de la mano negra, pues casi todos se quedan compadeciéndolos, y muchas veces me lo cuentan a mí mismo. A estos enemigos míos les he arrojado, como un pedazo de pan, el desprecio que me ha sobrado de otros desprecios más importantes (pág. 31).

¿Qué es este "juego de la mano negra"? Cualquier sugestión que ponga en duda la originalidad de su obra de precursor. Descubrimos una nota defensiva hasta en sus declaraciones más confiadas; ésta, por ejemplo: "Tengo tal seguridad en las cosas que hago que si el mismísimo señor D'Annunzio me atacara literariamente, lo sentiría mucho por él" (pág. 25).

"Si me atacara". Esta posibilidad la tiene siempre presente Huidobro. Al compararse con una locomotora, nota que así como los perros de las estaciones provincianas salen a ladrar a los trenes, de la misma manera le han ladrado a él ciertos chuchos literarios (pág. 32). Si un crítico encuentra en su poesía influencias de otros escritores, reacciona Huidobro como si lo hubieran acusado de plagio. Hasta a Armando Donoso, quien hizo el prólogo bastante favorable de La gruta del silencio, lo castiga Huidobro por haber notado en el libro influencias de ciertos poetas simbolistas (pág. 26).

Sus ataques contra los críticos hostiles son de una violencia increíble. Dice de una señora que había criticado una de sus poesías: "Esta desgraciada hembra lleva en el alma la joroba de un histrión"; la llama sordomuda, habla de su "coquetona estupidez" y de su "impotencia cerebral", e imagina a la pobre señora discutiendo los versos en la cama con su amante, director de un periódico de Santiago (págs. 92-93).

Al crítico de El Mercurio de Santiago le aconseja Huidobro que vuelva a enseñar el catecismo a los niños chicos y que no se meta más en cosas serias (pág. 101). Y dos críticos chilenos que habían cometido el error de censurar la obra de un amigo de Huidobro son víctimas de un ataque sobremanera cruel. Con toda clase de detalles repugnantes se burla el poeta de sus defectos físicos, y se complace en llamarlos invertidos (págs. 125-127). 
El viaje a Europa que emprende en 1916 no implica por parte de Huidobro un cambio de costumbres. Sobre este punto observa el poeta y filósofo español Juan Larrea en una carta al autor:

Era Huidobro persona de muchos conocidos pero de amigos contados en el mundo del arte. Su temperamento como de adolescente díscolo y un poco presuntuoso, unido a su condición de extranjero y de sudamericano, provocaba reacciones en contra suya entre las gentes del oficio, que acababan por indisponerse con él y negarle respeto.

Esta situación fué el resultado de una serie de controversias, unas literarias, otras puramente personales, en las que Huidobro seguía siempre el procedimiento adoptado en el colegio de jesuitas. Acusado, contesta con insultos. La situación va de mal en peor, y Huidobro adopta la postura de un mártir.

En cuanto a las polémicas literarias, todas tienen que ver con la cuestión de la originalidad de sus escritos. Impulsado por su manía no sólo de ser el gran iniciador sino de representarlo a toda costa, recurrió Huidobro a la dudosa maniobra de antedatar algunos de sus escritos con el fin de establecerse ante el público como único inventor del tipo de poesía que empezó a publicar en 1917. Todo ello fué absurdo, pues ni él ni sus llamados rivales inventaron las ideas cubistas o creacionistas. Pero contra toda evidencia persistía Huidobro en sus pretensiones, con el resultado contraproducente de poner en duda, injustamente, la autenticidad y el valor de su producción toda.

No poseemos hoy suficientes detalles para documentar con exactitud la disputa que inició esta serie de disgustos y que tuvo lugar entre los colaboradores de la revista cubista Nord-Sud, en la que publicó Huidobro doce poemas durante el año 1917. Los que con más claridad representaban el espíritu de Nord-Sud eran el director, Pierre Reverdy, y el poeta Paul Dermée. Los dos habían publicado artículos que definían la doctrina literaria del grupo llamado cubista, doctrina que coincidía con la teoría creacionista que defendía Huidobro en 1917 y 1918. A fines de 1917 riñeron Reverdy y Huidobro, 
y a partir de diciembre de aquel año dejó éste de figurar entre los colaboradores de la revista.

A causa de sucesos posteriores se cree generalmente que el motivo original de esta disputa fue el deseo obsesivo de Huidobro de atribuirse prioridades en materia de creación poética. Pero carecemos de datos precisos que nos permitan poner a prueba este juicio posterior a los hechos. Hay que añadir que por la misma época Reverdy, hombre huraño y desconfiado, riñó también con Paul Dermée. En este caso los detalles exactos son igualmente difíciles de reconstruir hoy día. El poeta Tristán Tzara, jefe en aquel entonces del grupo Dadá, declaró al autor, en una entrevista otorgada en París en 1953, que la cólera de Reverdy llegó al extremo de amenazarlo (a Tzara) con represalias inmediatas si se decidía a publicar algún escrito de Dermée.

Sea de ello lo que fuere, la querella entre Reverdy y Huidobro no hubiera tenido mayores consecuencias de no haber. publicado éste, durante una temporada que pasó en Madrid en 1918, un librito titulado El espejo de agua. Se trataba de unas poesías cortas que ya se habían publicado en versión francesa, con la excepción del poema "El Espejo de agua" y de otro poema nuevo, "Arte poética", en el que resumía Huidobro la teoría creacionista. El libro llevaba en la portada el rótulo "segunda edición", y se leía a continuación esta nota: "La primera edición de esta obra se publicó en 1916".

Sostuvo Huidobro ante sus compañeros madrileños que esta "primera edición" la había publicado en Buenos Aires, en donde había estado de paso rumbo a París; pero como nadie viố nunca semejante edición, que no se encuentra hoy en la Biblioteca Nacional de Buenos Aires, se difundió poco a poco la creencia de que la publicación de una supuesta segunda edición había sido una impostura debida al afán de originalidad del poeta chileno. En 1920 el poeta ultraísta Guillermo de Torre publicó en Madrid un artículo en que le echó en cara la falsificación. 9

Lo característico de Huidobro fué el no dar el brazo a

9 Guillermo de Torre, "La poesía creacionista y la pugna entre sus progenitores", Cosmópolis, V, 20 (septiembre de 1920), pág. 592. 
torcer. Sin contestar directamente a la acusación de Torre, se permitió hablar con desprecio de los "pobres ultraístas", en un artículo publicado en París en 1921. Es el primero de sus escritos en que afirma haber inventado el creacionismo antes de llegar a Europa; insiste en que había hecho su descubrimiento bajo el estímulo de las palabras de un poeta indígena de raza aymara, y que había explicado la teoría en una conferencia pronunciada en el Ateneo de Buenos Aires en 1916, fecha de la supuesta primera edición de $E l$ espejo de agua. 10

Herido por el desprecio de su ex-maestro, Guillermo de Torre amplificó sus ataques en una serie de artículos reunidos después en un libro publicado en Madrid en 1925 bajo el título de Literaturas europeas de vanguardia. Alegaba Torre que lo que el chileno no había tomado directamente de Reverdy lo había copiado de las metáforas de Julio Herrera y Reissig (pág. 121). Había dado en el blanco. Reaccionó Huidobro como ante una acusación de matricidio o de antropofagia. En 1924, habiendo visto algunos de los artículos de Torre, publicó como respuesta un suplemento castellano de su revista parisiense Création. Reproducida en una revista chilena, esta obra, ejemplar en su vilipendio, llenó veintiséis páginas, de las cuales veinticuatro estaban dedicadas a un ataque personal contra el enemigo. Se burla de los gustos literarios de Torre, cita anécdotas crueles en contra suya, y, por fin, hace esta afirmación: Guillermo de Torre lo ha atacado porque habiendo imitado ciegamente a Huidobro en su poesía, lo cree responsable del poco éxito de su libro Hélices:

Me dicen que me cree, injustamente, to juro, la causa del fracaso de su libro. Hijo querido ¿qué culpa tengo yo de que Ud. sea un tan incomensurable poeta que sólo puede gustar a Dios y a sus santos? Ud. no nació para este mundo sino para el otro. Suicídese y verá que no miento.11

10 "La Creación pura", Antología, pág. 254. Este articulo salió en francés en L'Esprit Nouveau, abril de 1921, y como prólogo de Saisons cboisies.

11 Vicente Huidobro, "Al fin se descubre mi maestro", Atenea, II, 7 (30 de septiembre de 1925), págs. 218-244. Ya había salido en Création, 3, febrero de 1924. 
Deseoso de mantener una posición de jefe de grupo, se negaba Huidobro a identificarse con movimientos literarios que no fueran el suyo. Se resistía a seguir la moda cuando en 1919 algunos de sus ex-camaradas de Nord-Sud pasaron al movimiento Dadá. Desde 1918 empezó a cambiar cartas con Tristán Tzara, pero en 1920, cuando le hizo saber Tzara que pensaba publicar algunas poesías suyas en una antología Dadá, le pidió Huidobro que quitara los poemas del libro o pusiera un rótulo rectificativo haciendo constar que el autor de Horizon carré no pertenecía al movimiento. En su única colaboración en una publicación Dadá se dedicó Huidobro a hacer una defensa del cubismo, ya letra muerta para los demás colaboradores. 12

No podemos salir del período creacionista, que termina en el año 1925, sin hablar de los escándalos personales en que mostró Huidobro una testarudez que contribuyó al desmedro de su prestigio de artista. Empezó con un presunto episodio de secuestro, que tiene por lo menos el valor de ser pintoresco; este "secuestro" se originó en la publicación, por parte de Huidobro, de un librito en prosa titulado Finis Britannia, que vió la luz en diciembre de 1923 y que fué presentado como la narración de las actividades antibritánicas de cierta Sociedad Alpha, pero que no parece haber sido otra cosa que una pirueta sugerida por las entonces dificultades en la vida internacional de Irlanda. Los amigos del poeta, acostumbrados a sus extravagancias, no le dieron mayor importancia. A los cuatro meses, o sea en marzo de 1924, desapareció Huidobro por varios días de su apartamento parisiense. Su esposa recibió una carta anónima en la que se le decía que el poeta estaba preso "bajo siete llaves"; cuando volvió Huidobro a casa, le dijo a su señora y a la policía que en la Puerta de Auteuil to habían secuestrado unos agentes secretos británicos, quienes lo habían encerrado en un castillo, tratando sin éxito de hacerle repudiar sus ataques contra el imperialismo.

La reacción a este relato fué algo escéptica. El comisario de policía insinuó que se trataba de una escapada con otra

12 "Vol-au-vent", en Le Cocur à Barbe, joumal transparent, Paris, abril de 1922. 
mujer, aconsejándole a Huidobro que no insistiera en una investigación detallada. Fiel a su carácter intransigente, se negó Huidobro a retractarse de sus afirmaciones. Convocó a los periodistas y, en una entrevista, acusó de incompetente a la policía, la que, decía, se había negado a ayudarle porque era el autor de poemas "incomprensibles" y porque frecuentaba el café La Rotonde de Montparnasse. Él iba a investigar el asunto por su cuenta, con la ayuda de un abogado y de un detective particular. Lo habían secuestrado, insistía, por sus escritos antibritánicos, y porque formaba parte de una sociedad secreta irlandesa dedicada a la destrucción del imperialismo británico. 13

Esta insistencia en mantener una actitud creacionista para con su vida privada, le costó a Huidobro la amistad de su compañero y maestro, el pintor Juan Gris, y con la amistad de Gris perdió el respeto de otros muchos. Pero no aprovechó la lección; hubo de afirmar, en un libro publicado en 1926, que una vez había pasado tres días en Dublín, perseguido por la policía inglesa, durmiendo cada noche en una casa distinta para mayor seguridad. ${ }^{14}$

Para ver el interés que tenía Huidobro en hacer el papel de mártir, no hay más que recordar los dos libros en prosa que publicó en 1925 y 1926. Manifestes, resumen de la teoría creacionista, nos presenta al mártir literario en el capítulo final, "Les Sept paroles du poète". Se trata nada menos que de una paráfrasis de las últimas palabras de Jesucristo. Los verdugos del poeta, víctima expiatoria, son los que no comprenden. El autor hace hincapié en las frases "mon père, pardonnez-leur, car ils ne savent ce qu'ils font", e "ils m'ont calomnié". La última frase, claro está, se refiere a los que lo habían acusado de plagio. ${ }^{15}$

En Vientos contrarios entra el mártir de la libertad personal. Tenemos que vérnosla esta vez con otro escándalo personal. Es bien sabido que durante una visita que hizo a Chile en 1925 y 1926 enamoró Huidobro a una señorita principal.

13 Cito un recorte de Paris-Joumal, marzo de 1924, de la colección de Juan Larrea.

14 Vientos contrarios, pág. 57.

15 Manifestes, págs. 101-103. 
La chica fué recluída por sus padres, y frente a amenazas bastante serias por parte de la familia de ella, el amante se vió obligado a regresar a París a fines de 1926. Vientos contrarios que salió en Santiago en agosto de 1926, es una colección de ensayos y aforismos que responden en parte al deseo del autor de justificar su conducta ante la sociedad chilena. Tampoco aquí se muestra dispuesto a ceder. El libro es una especie de desafío, y el autor es, una vez más, el hombre excepcional mal comprendido por mentes inferiores. "Los perros le ladraban", dice un aforismo, "porque iba vestido de excepción" (pág. 60). Amante generoso que lucha por romper las barreras impuestas por una sociedad hipócrita y cobarde, sus argumentos principales son una moral nietzscheana, cuya expresión más extremada es la frase "después del diluvio, yo" (pág. 73), y el cliché romántico de que el amor vence todos los obstáculos, o como dice él, "el amor no es cuestión de derechos sino de hechos" (pág. 181). Menosprecia a los que violan sus sentimientos por obedecer a la tradición: "Se llama hombrín al que ahoga su corazón, domina sus audacias, y encauza los actos de su vida según el parecer de los demás" (pág. 75).

Aprobemos o no los sentimientos expresados en Vientos contrarios, hay que reconocer que no eran meras palabras. De París volvió Huidobro a América, y después de pasar una temporada en Nueva York, se dirigió a Chile, donde llevó a cabo el rapto de la muchacha. En 1928 inició con ella un nuevo período de vida en París.

Este periodo, que termina con la vuelta de Huidobro a Chile en 1932, se distingue por un cambio radical en su poesía, cambio que se hace notar en el largo poema Altazor, publicado en Madrid en 1931. Los comienzos de Altazor datan de 1919, y en la portada de la versión de 1931 se leen las palabras "poema en VII cantos (1919)". Esto da a entender claramente que toda la versión final corresponde a esa fecha.

Resulta difícil creerlo. Por ejemplo, en la portada de Vientos contrarios (1926) se anuncia como próximo a publicarse "Altazur (sic), poema". En el mismo libro se encuentra la frase "aquí he escrito el capítulo quinto de mi Altazur (sic)". Esto pone en duda la afirmación del autor, ya que 
en la versión de 1931 el poeta emplea la palabra "Altazor" como combinación significativa de 'alto' y 'azor'. Así leemos en el canto IV: "Aquí yace Altazor, azor fulminado por la altura” (pág. 72).

En la página 65 de Altazor, como observa Juan Larrea en una carta inédita al autor, se encuentran unos versos casi idénticos a un poema de Huidobro titulado "Venus", que publicó Larrea en octubre de 1926 en su revista Favorables Paris Poema. Huidobro le había entregado el poema a Larrea, a su petición de originales para la revista y sin hacer mención de Altazor, poema de que casi nunca habló con Larrea antes de 1928. A partir de 1928 empezó a mencionárselo con frecuencia, leyéndole trozos que Larrea suponía compuestos hacia aquella época.

Sin entrar en un examen detallado del texto de Altazor, mencionaremos un solo pasaje, que parece establecer que hasta el canto I fué refundido mucho después de 1919. Es notorio que la estética que abrazaba Huidobro en 1919 excluía de la poesía elementos didácticos y filosóficos. No obstante, en la página 21 de Altazor se habla de la "muerte" del cristianismo, "que sólo ha enseñado plegarias muertas"; en la misma página se alude en términos comunistas a la revolución rusa:

\footnotetext{
Mirad esas estepas que sacuden las manos Millones de obreros han comprendido al fin $Y$ levantan al cielo sus banderas de aurora Venid venid os esperamos porque sois la esperanza

La única esperanza

La última esperanza
}

No conocemos datos que indiquen que Huidobro se haya interesado por la política revolucionaria en 1919, pero sí sabemos que en 1931 tenía relaciones estrechas con el partido comunista. Existen, pues, motivos para creer que el dar para la composición de Altazor la fecha de 1919 fué otra de las tentativas del poeta de establecerse como innovador. $Y$ esto se hace más probable aún si tenemos en cuenta que el poema muestra algunas influencias del superrealismo que Huidobro 
había atacado en Manifestes, en 1925. Se repite una situación similar a lo ocurrido con El espejo de agua, sin duda. En la carta ya mencionada, Juan Larrea concluye: "Lo cierto es que, en vez de engañar a nadie, sólo conseguía desacreditarse funestamente ante amigos y compañeros". Desde luego, nos apresuramos a aclarar, como lo hace el propio Larrea, que estas observaciones no tienen por fin un ataque a la memoria de Vicente Huidobro, y que sólo las referimos porque creemos que son esenciales para conocer un aspecto de la personalidad de nuestro poeta, la cronología verdadera de su producción y los valores esenciales y positivos de su poesía. Que Huidobro intentara el escándalo para hacerse notar, no cabe la menor duda. Baste recordar otro episodio, aunque más no sea porque revela la relación, muy significativa por cierto, con su máximo rival, el poeta Pablo Neruda. Ocurrió hacia 1937, cuando Huidobro y Neruda debían tomar parte en un congreso de escritores organizado por la Asociación Internacional para la Defensa de la Cultura, brazo intelectual del Frente Popular durante los tiempos de la España republicana.

Las verdaderas causas, los detalles y aún los resultados literarios de la enemistad de Huidobro con Neruda son tan ingratos como difíciles de documentar certeramente. Pero su trascendencia debió ser de gran repercusión, puesto que la organización patrocinante del congreso envió, en carta abierta fechada en París el primero de mayo de 1937, una recomendación o invitación de que olvidaran sus diferencias en favor de la causa común y hasta de la unidad del movimiento. ¿Qué estos escándalos responden a un tipo de psicología particular o a una situación especial que, en el caso de Huidobro, nos muestra un tipo característico de señorito mimado? Sin duda todo esto puede ser admisible y hasta verdadero. Pero ¿qué importancia pueden tener estos hechos de la vida externa del poeta que hemos mencionado para un juicio sereno y desinteresado de su obra? ¿Acaso un señorito mimado no puede ser un excelente poeta? Admitir esto sería lo mismo que afirmar que Villón no fué poeta porque era ratero. Un estudio detenido y desapasionado nos induce a sostener más bien que las llamadas polémicas literarias de Huidobro nada tienen que ver con su poesía en sí, sino solamente 
con una cuestión de influencias y prioridades. $\mathrm{Y}$ eso es todo y no mucho por cierto. Lo que corresponde hacer, por tanto, es aceptar como fecha definitiva la de 1918 para El espejo de agua, y si todo Altazor no fué escrito en 1919, esto prueba que, como otros poetas, Huidobro refundía algunos escritos suyos a medida que pasaba el tiempo. La causa de todos sus males fué el no querer reconocer que era hombre y no dios. La misma altura de sus pretensiones hizo que se le juzgara con una severidad quizá excesiva. Espero poder demostrar en otra ocasión que existe el revés de la medalla, que las mismas pretensiones y la misma terquedad que tanto perjudicaron su carrera le dieron la fuerza y la persistencia necesarias para explorar, en el trágico abismo de Altazor, un terreno no visto por ningún otro poeta de habla española. Pero antes de emprender esa tarea es necesario abandonar para siempre el absurdo debate sobre quién "inventó" el creacionismo. Examinemos sin parti pris los escritos "pre-creacionistas" de Huidobro para ver con qué ritmo germinó y creció su poesía.

\section{I}

Inició Vicente Huidobro su carrera literaria cuando ya el modernismo cansaba a los poetas. Tanto en Hispanoamérica como en España se había hecho notar una reacción contra el Darío de Prosas profanas. 'El mismo Darío buscaba, a partir de Cantos de vida y esperanza, una poesía más directa, más hondamente humana. En general, a partir de 1910 se hacía sentir un nuevo clima poético, en el que junto con el abandono de lo artificioso y superficial del primer modernismo y una como vuelta a la "realidad", se notaba un interés por explorar, de manera más clara y directa, los problemas psicológicos y filosóficos del individuo en relación con el mundo y el infinito.

Pero este nuevo clima poético no fué el resultado de una ruptura con el pasado; fué evolución y no revolución. "Dominaba todavía la métrica tradicional, y se repetían en tono menor los temas románticos. Cuando canta Rubén Darío su 
cansancio y su desengaño, reconocemos actitudes comunes desde la época de Chateaubriand. Propio de este período es una exploración del sentido del paisaje, entendido como la proyección emocional del poeta dentro de la naturaleza. El poeta reconoce así su comunión con el mundo. Este vago panteísmo, tema romántico por excelencia, lo resume el poeta mexicano Enrique González Martínez:
A veces una hoja desprendida de lo alto de los árboles, un lloro de las linfas que pasan, un sonoro trino de ruiseñor, turban mi vida.
Vuelven a mi, medrosos y lejanos, suaves deliquios, éxtasis supremos; aquella estrella y yo nos conocemos, ese árbol, esa flor, son mis hermanos:16

Como Darío, buscaba González Martínez una expresión más profunda. Habla más de una vez de la necesidad de penetrar por debajo de la superficie de las cosas:

\footnotetext{
Busca en todas las cosas un alma y un sentido oculto; no te ciñas a la apariencia vana; husmea, sigue el rastro de la verdad arcana, escudriñante el ojo y aguzado el oído.

No seas como el necio que al mirar la virgínea imperfección del mármol que la arcilla aprisiona queda sordo a la entraña de la piedra, que entona en recóndito ritmo la canción de la línea.17
}

En Chile, la generación de Huidobro había de crear una oleada de interés por una poesía inaudita en aquel país. Pero tenía que luchar contra lo que un crítico chileno recuerda como "nuestro inconexo y prosaísta ambiente literario, aun fuertemente dominado por infolios de mala crítica y buena

16 "A veces una hoja desprendida", de Silenter, incluido en Aniología poética (México, 1949).

17 "Busca en todas las cosas", de Los senderos ocultos, en Antologín. 
memoria, historiadores eruditos como no los hubo en América, y bardos de artificiosa preceptiva". 18

Vislumbramos el gusto del público de la época en una colección de versos juveniles que publicó Huidobro en 1910, a los diecisiete años. Ecos del alma parece ser un cuaderno escolar olvidado en alguna caja de recuerdos; una de las poesías, "Despojo santo", hasta lleva una dedicatoria "a mi sabio profesor de retórica, el Rvdo. P. Rafael Bonada". Más tarde Huidobro consideró su libro como romántico, retórico y hueco, pero cometió una injusticia al juzgarlo según las nuevas normas de la crítica literaria. Colección de ejercicios que da la sensación de una parodia de alguna antología del siglo pasado, sólo debe servirnos como muestra de los comienzos de un aprendizaje literario.

Empezando con la glosa de algunos versos de Bécquer, contiene el librito un poema gauchesco, dos leyendas indígenas, otra de un pueblo de pescadores que pierde y recobra una imagen milagrosa, un soneto a Colón, traducciones de Heine y de Güerrini, y un poema épico sobre la Guerra del Pacífico. "La Epopeya de Iquique", que está dedicada al almirante chileno Arturo Prat, comienza con el verso "Qué soy yo, Prat, para cantar tu gloria?" Notamos, de paso, los versos de circunstancia celebrando los amores que culminaron en el casamiento de Huidobro con Manuela Portales Bello. " das?", como otros versos de álbum incluídos en el libro, evoca estampas románticas:

\footnotetext{
¿Recuerdas? Con su dulce melodía sollozaba Beethoven en el piano, $y$ evocado de nuevo por tu mano más romántico y tierno parecía.
}

Si en esta mezcla de géneros y estilos pudiera encontrarse un tema común, sería el del terror a la muerte y al más allá, preocupación natural en el hijo de tan católica familia como parece haber sido la suya. El tono es melodramático, como en "Al cementerio":

18 Julio Molina, "Vicente Huidobro", Atenea, año XXV, tomo IXXIX, núms. 271-272 (enero-febrẹro de 1948), págs. 56-78. 
¿No veis allá aquel campo silencioso que se extiende detrás de un monasterio? Es el lóbrego y triste cementerio Es el campo del último reposo.

Bajo esa verde y natural alfombra iqué bien el cuerpo debe reposar!

En tanto al alma el más allá le asombra.

El melodrama se convierte a veces en algo inconscientemente cómico. Escribe en "Nocturno": "Yo quisiera temblar bajo esas fosas/ yo no temo la muerte y los gusanos/ que de la larva salen mariposas/ que son todos los muertos mis hermanos". El tema del cementerio vuelve con frecuencia; "El toque de ánimas" recuerda "La oración por todos" de Andrés Bello; en "Flores muertas" una joven deja flores en la tumba de su novio y se mete a monja; y "Amor de madre", que también muestra la tumba de un malogrado, da el contraste entre la fidelidad de la madre y la "falsedad" de la viuda que ha vuelto a casarse: "Mujer mentida, corazón de nieve,/ El viento se llevó en su raudo vuelo/ las palabras de amor que le dijiste,/ los traidores y falsos juramentos".

Puede que la emoción sea sincera, pero por no dominar el lenguaje el aprendiz de poeta no llega a comunicársela al lector. No hay para qué detenernos en los ritmos torpes, las rimas mecánicas, las inversiones incómodas, las frases convencionales y los adjetivos superfluos, como cuando habla, en "Flores muertas", de un instante "breve", una tumba "solitaria", una rama "marchita" y una losa "fría". Notemos, en cambio, el énfasis que pone Huidobro en la muerte; es esto sin duda la cosa más natural del mundo, y sin embargo el prólogo de Ecos del alma, con su receta del poeta ideal, nos permite atisbar otros motivos, pues nos enseña que el interesarse por la muerte es lo propio del poeta: "Qué poeta no pretende dormir su último sueño bajo un sauce en un abrupto peñón azotado por las olas del mar, a la sombra de una cruz blanca con su verde enredadera de pasionarias...?" (pág. vii).

Es decir, que ciertos temas, entre ellos la muerte, son 
poéticos en sí. Parece justo deducir de Ecos del alma que Huidobro empezó a escribir con la actitud romántica de que lo poético de una obra literaria reside sobre todo en el tema mismo, más que en la manera de presentarlo. A juzgar por su falta de interés por la forma, no conocía la noción de poesía como oficio. Este punto es de importancia capital para el estudio de Huidobro, porque las teorías creacionistas que empezó a proponer en 1917 son del todo opuestas a la actitud que acabamos de describir. Será necesario buscar los orígenes de cambio tan radical.

Empecemos por olbservar que las páginas de Ecos del alma carecen en absoluto de influencia modernista. Tampoco se ven huellas de los autores franceses que dió a conocer Rubén Darío en América. Para encontrar tales influencias, hay que pasar a los libros que publicó Huidobro en 1914.

Uno de éstos es la colección de ensayos Pasando y pasando, ya citado. No todo el libro está dedicado a sus polémicas, y contiene por tanto suficiente material de interés general como para demostrar que desde 1910 se había ensanchado notablemente el horizonte literario del joven poeta. Entre otros muchos autores, ha leído a los modernistas y a los simbolistas, adquiriendo actitudes de moda que se avenían perfectamente con su propio carácter voluntarioso. Aprueba toda manifestación de rebeldía y de innovación, odia los clichés y los "fósiles literarios", y comparte el desprecio que sentían por el público los poetas de la torre ebúrnea; desea para sus libros "el ataque rudo de la noble mediocridad imperante en estas tierras. Quiero que mis libros queden muy lejos de la visual de las multitudes y del vientre de la sana burguesía" (págs. 27-28).

El poeta debe evitar lo mediocre y buscar los extremos: "Mientras menos ojos nos alcancen, más alto o más hondo vamos... yo amo las grandes cumbres y los grandes abismos. Lo que da vértigo" (pág. 31). Abriéndose paso por sí solo, logrará el poeta la sinceridad necesaria para la expresión de una visión personal. Implica esto escepticismo en materia de religión y filosofía: "Hoy no creo firmemente en nada. Estoy convencido que los filósofos sólo dan palos de ciego y que la 
verdad verdadera sólo está en la médula cerebral de Dios Nuestro Señor, suponiendo que Dios exista" (pág. 35).

Juzga de la misma manera las doctrinas estéticas: "Para mí no hay escuelas, sino poetas" (pág. 30). El simbolismo, por ejemplo, no es un movimiento histórico sino una provechosa fuente de técnica poética: "Que el simbolismo ya murió? Ni vive ni ha muerto; es una de tantas maneras como hay en el arte" (pág. 145).

Del simbolismo ha aprendido Huidobro las ventajas del "arte del sugerimiento", nombre que da a un estilo rápido y alusivo. Consiste en apuntar a grandes rasgos lo esencial del pensamiento sin enlaces ociosos. De ese arte de sugerir da este ejemplo, con su retoque de sátira local:

Le dais a un retórico como tema algo sobre el cementerio y os diría: La gran tristeza del cementerio me llena de dolor y de oscuros pensamientos y maquinalmente evoco todo lo que tiene relación con él. Me acuerdo de Hamlet cuando tomó la calavera de Yorrick y lloró sobre su recuerdo, pienso en don Juan cuando dialogó con el comendador... etc., etc., y si queréis, podéis agregar al señor García Gómez, que hace votar a los muertos.

Le dais el mismo tema a otro escritor, si queréis más moderno, y os diría: La gran tristeza evocativa de los cementerios. Hamlet, don Juan, García Gómez (págs. 145-146).

Es de mucha importancia para el desarrollo del futuro creacionista su descubrimiento de la necesidad de evitar imágenes gastadas y de crear metáforas nuevas. "Guerra al cliché... que si hay una montaña no sea una alta o encumbrada cima. Es preferible que sea una montaña que dialoga con el sol o con pretensiones de desvirgar a la pobre luna" (pág. 142).

Estas imágenes no se conciben como decoración; están relacionadas con la jdea simbolista de las correspondencias ocultas entre objetos dispares, correspondencias que debían ser reveladas por la yuxtaposición de palabras tomadas de campos sin previa conexión en la mente del lector. Huidobro formula la idea de esta manera: "Admiro a los que perciben las relaciones más lejanas de las cosas. Admiro a los que saben escribir versos que se resbalan como la sombra de un 
pájaro en el agua y que sólo advierten los de muy buena vista" (pág. 30).

Se llega a esta visión mediante un cultivo minucioso de la conciencia individual, "recogiéndonos en nosotros mismos, analizando con un prisma nuestro yo, volviéndonos los ojos hacia adentro" (pág. 144). Pero este recogerse en sí mismo no implica la negación del mundo de la naturaleza; se emplea como medio de lograr una fusión entre el alma del poeta y la del paisaje: "El alma del poeta debe estar en contacto con el alma de las cosas" (pág. 30).

He aquí el tema de Las pagodas ocultas, serie de "salmos, parábolas y poemas en prosa", publicados igualmente en 1914. Haciendo eco de la corriente panteísta que anima los versos que citamos de González Martínez, trata Huidobro en este volumen del cultivo de las pagodas ocultas del alma, y de la relación entre el alma y la naturaleza. Dice al alma: "Has de amar a la naturaleza con un deslumbramiento fervoroso $y$ has de estar siempre dispuesta a los más grandes estupores. Busca siempre el verdadero sentido de todo. El sentido de los árboles, del río y del fuego, el sentido de las montañas y de la noche, el sentido de la tierra y del aire, del amor y del dolor" (pág. 13). Así se unen panteísmo y la teoría de las correspondencias; el mundo es un gran almacén de significados que han de descubrirse por medio de la metáfora.

El que Huidobro haya ensayado en Las pagodas ocultas el poema en prosa, indica el interés que va mostrando por la cuestión de la forma. Es interesante notar que en un artículo de Pasando y pasando aprueba el verso libre del simbolista francés Gustave Kahn, llamándolo "una mezcla de ritmos armoniosa en su conjunto y perfectamente rimado en consonante o asonante" (pág. 167). Era natural que adhiriera Huidobro a un movimiento que tendía hacia la abolición de las normas convencionales, $y$ de hecho las palabras citadas describen exactamente la forma de algunas poesías suyas de la época. Amigo de la libertad, alaba la libertad de forma que proponían los futuristas, así como su actitud de rebeldía. Elogia en términos bastante vagos la poesía de Marinetti, jefe del movimiento, pero desprecia gran parte de la doctrina futurista. Para él, el tema preferido de los futuristas, la belleza 
de la violencia, la energía y la velocidad, no era nada nuevo. "Lea, si no, el señor Marinetti, la Odisea y la Ilíada, la Eneida o* cualquiera de las Odas de Píndaro a los triunfadores en los juegos olímpicos, y encontrará allí toda su gran novedad" (pág. 166). Se burla del amor que profesaban los futuristas por la industria moderna, sus productos y medios de transporte: "El señor Marinetti prefiere un automóvil a la pagana desnudez de una mujer. Es ésta una cualidad muy de niño chico: el trencito ante todo. Agú Marinetti" (pág. 167).

Aquí Huidobro, a pesar del interés que empieza a tener por cuestiones de forma, comparte todavía con los futuristas la idea romántica de que algunos temas son más poéticos que otros. En Manifestes, escrito durante el período creacionista, había de atacar a los futuristas desde otro punto de vista: "Ce n'est pas le motif mais la façon de le produire qui fait la nouveauté. Si je chante l'avion avec l'esthétique de Victor Hugo, je serai aussi vieux que lui, et si je chante l'amour avec une esthétique nouvelle, je serai nouveau" (pág. 64).

Diremos, pues, que en Pasando y pasando está Huidobro todavía bastante lejos de la posición creacionista. Es cierto, sin embargo, que gracias a sus lecturas ya tiene un criterio más amplio, y que en cuestiones de forma ha iniciado la marcha hacia lo que un día será la severidad del creacionismo.

La poesía que escribía Huidobro durante esta época puede leerse en dos tomos terminados a fines de 1913 y publicados en 1914, Canciones en la noche y La gruta del silencio. Canciones en la noche, que debió salir primero, fué publicado después del otro libro, dice Huidobro en una nota preliminar, "como una muestra de mi evolución entre aquel primer libro romántico de los diecisiete años, Ecos del alma, y La gruta del silencio, libro que quiero y del cual estoy plenamente satisfecho". De Canciones en la noche dice con franqueza: "con excepción de algunas composiciones, no tengo a este libro gran cariño".

Salta a la Vista el motivo de estas disculpas. Aparte versos de circunstancias como "El madrigal de los besos" ("Oye, diablesa de los ojos negros/ yo quiero madrigalizar tus besos/ pero si tú no me dejas probarlos/ i cómo podría madrigalizar- 
los?'), Canciones en la noche es otro libro de ejercicios como Ecos del alma. Es interesante notar, de paso, con qué seriedad publica el joven este documento como servicio a la crítica.

Aquí sirven de modelos Rubén Darío y otros modernistas. Hay unas cuantas imitaciones directas de poemas conocidos; así la "Balada para el Marqués de Bradomín", quien "con el misterio de su abracadabra/ hace vibrar cada palabra", remeda el soneto de Rubén "Este gran don Ramón", dedicado a Valle-Inclán. Incluye también una "Salomé" parnasiana, basada en las escenas bíblicas de Guillermo Valencia:

\footnotetext{
$Y$ tiembla y vibra $y$ arde la voz sensualizada

De Salomé: -Quiero besar tu boca Joanan.

-Quita, hija de Sodoma! ... La luna está encarnada

$Y$ las estrellas sobre la tierra lloverán.

Va su triunfo girando en la danza de los velos

$Y$ canta una victoria cada uno de sus pasos,

Una danza que es frotación de terciopelos,

Reptilesca, felina, con suavidad de raso.
}

Son versos de aprendiz, pero demuestran un conocimiento nuevo de las posibilidades del lenguaje. Se inicia Huidobro en el empleo de las palabras como elementos de una construcción planeada. Aquí importa el tema porque hace posible la evocación de luz, color, textura. En vez de recurrir al ripio, utiliza el verso según le conviene, con cesura movediza y enjambement. El vocabulario refleja las ricas telas y vivos colores del primer modernismo, y los adjetivos, salvo un dudoso 'sensualizada', han aumentado en poder y precisión. Ya empezaba Huidobro a aprender el oficio.

El interés por la forma lo llevó a unos experimentos métricos reunidos en Canciones en la noche con el título de "Japonerías de estío". Estos poemas representan una vuelta al juego alejandrino de dibujar la silueta del sujeto del poema mediante la distribución de las palabras en la página. "La capilla aldeana" forma la fachada de una iglesia con su cruz. Otro arreglo por el estilo se llama "Nipona": 


\author{
Ven \\ Flor rara \\ De aquel edén \\ Que llaman Yoshiwara \\ Ven muñequita japonesa \\ Cabe el maravilloso estanque de turquesa \\ Bajo un cielo que extienda el palio de ónix de su velo \\ Deja que bese \\ Tu rostro oblicuo \\ Que se estremece \\ Por un inicuo \\ Brutal deseo. \\ Oh, déjame así \\ Mientras te veo \\ Como un biscuit. \\ Son tus ojos dos gotas ovaladas y enervantes \\ En tu rostro amarillo y algo marfileño \\ $\mathrm{Y}$ tienes los encantos fascinantes \\ De un ficticio y raro ensueño. \\ Mira albas y olorosas \\ Las rosas \\ Té.
}

Por estas fechas Guillaume Apollinaire se entregaba en París al mismo juego, cuyos resultados hubieron de formar en 1918 el conocido libro Calligrammes. De acuerdo con su gran afición por las artes plásticas, se preocupaba Apollinaire, como los futuristas que frecuentaba en 1913, por la posibilidad de agregar a la poesía una dimensión visual. Así Apollinaire y los de su grupo, al cual se asoció luego Huidobro, hacían hincapié en una poesía de imágenes visuales, y hablaban de los problemas de la poesía en términos pictóricos. Un poema como "Nipona" nos interesa porque nos muestra un Huidobro joven dispuesto, antes de ir a Europa, a compartir los intereses del grupo cubista.

Por lo demás, "Nipona", con su vocabulario preciosista, su exoticismo a flor de piel, su decadencia de lance, su artificialidad juguetona y su referencia a "los encantos fascinantes de un ficticio y raro ensueño", es un buen ejemplo del clima del primer modernismo de gran parte de Canciones en la noche. Un mundo crepuscular, traducido en acuarela, se presenta en el poema "Estas trovas": 


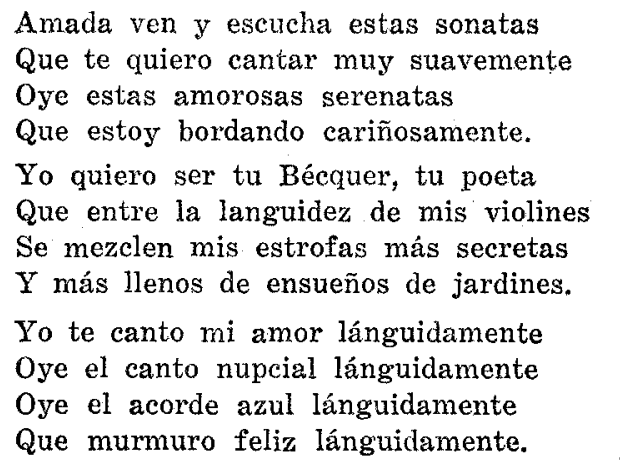

Todo el poema es un tesoro de frases hechas modernistas. El clima es íntimo, y el autor aspira a una galantería delicada. Se burla de las reglas al atentar el tour de force de las repetidas rimas en 'mente', con miras a establecer una cadencia arrulladora apropiada para un ambiente de "ensueños de jardines". La palabra clave es naturalmente 'languidez'. Vemos las típicas comparaciones entre poesía y música, y para su música escoge el poeta violines, sonatas y serenatas, música de cámara para acompañar el murmullo de su canto. Su 'acorde azul' recuerda no sólo a Rubén Darío sino toda la teoría simbolista de las correspondencias entre color y sonido. A lo largo de "Estas trovas" vuelven ciertas palabras, 'azul', 'lánguida', 'jardines', como el leit-motiv para dar al poema la unidad de una composición musical.

En lugar de la desesperación teatral que inspiraba en Ecos del alma la idea de la muerte, encontramos en Canciones en la noche una melancolía conforme al tono moderado del modernismo. El tema, consagrado por románticos y simbolistas, es el dolor predestinado del artista, llamado en "Estas trovas" el "dolor de poesía". Habla en "Rosas de galantería" de "mi desvarío", "mi vejez de veinte años", y "mi camino largo", siempre con respecto a su condición de poeta. Conviene notar aquí que esta actitud, tan de moda a fines del siglo pasado, fué condenada por los poetas cubistas, quienes luchaban, con éxito. desigual, por extirparla de. su propia poesía. Max Jacob la atacó bajo el nombre de "hamletismo".19 
El "hamletismo" atraía mucho a Huidobro. En "El augurio fraterno", dedicado a un poeta amigo, llama a la vida de un poeta "el largo sendero", habla al amigo de "la aristocracia de tu real soledad", dice que padece el amigo "la angustia de un voluptuoso mal/ que será la que en los siglos te corone inmortal", y concluye, "al fin de tu vida está la neurastenia/ como una novia pálida, ojerosa de anemia".

Para Huidobro el "mal du siècle" era, como la muerte, un tema especialmente poético, y seguía siéndolo en el otro libro de versos publicado en 1914, La gruta del silencio. Una de las poesías de esta colección, "La balada triste del largo camino", está dedicada "a los hermanos que sufren el latigazo de su bohemia". Es el destino del poeta "seguir el largo peregrinaje por/ la tristeza amarilla de los caminos/ donde nieva la luna todo su albor... auscultando emociones/ $\mathrm{y}$ acechando con miedo a la "Dama de la Hoz". Habla Huidobro en "El poema para mi hija" de "mi dolor de arte/ mi amor a las alas de cisne/ mi fervor a lo triste y a lo grande/ $\mathrm{mi}$ terror a la vida que sigue".

El poeta sufre por su arte; sus creaciones son a la vez el producto y el consuelo de su martirio. Escribe en "Coloquio espiritual, I":

Que husmees y que busques en tu dolor $\mathrm{Y}$ en la aristocracia de tu real tristeza Toda la teología de tu interior

Toda la gama rica de tu realeza.

Y continúa en el segundo "Coloquio espiritual": "Ama tus obsesiones, aumenta tus martirios/ no olvides que en ti llevas un loto azul: el Arte".

En los poemas que acabamos de citar, el presentimiento de la muerte es un tema secundario asociado al del "dolor de poesía". En otros versos es el tema principal. En "La araña negra", el poeta ve en su cuarto esta "fosca anunciadora de la muerte". "El terror de la muerte", otra versión del tema, principia así:

Yo he visto la muerte que ha entrado a mi cuarto, han crujido las tablas al pasar por encima, 
ha pasado como un humo blanco

y ha ido a acurrucarse a un rincón, a una esquina donde pinta la sombra largos andrajos.

Así, el deseo de tomar una actitud "poética" sigue influyendo en la poesía de Huidobro, como en su conducta. En el prólogo de La gruta del silencio, el crítico Armando Donoso señaló los peligros de la imitación de un "pesimismo" que en el caso de un Verlaine "responde a una razón profunda de sinceridad y de dolor vivido", dando a entender que no tiene Huidobro la misma justificación: "Ha comenzado en su estudio por donde otros hubieran terminado".

Es justo observar que en la obra de su madurez trató Huidobro con plena sinceridad los temas eternos que ensayó con éxito desigual durante su aprendizaje; pero conviene fijarnos por el momento en otra observación del prólogo de Armando Donoso. Se queja el crítico chileno de ciertas violaciones intencionales al gusto y a la métrica oficiales. Encuentra un deseo de hacer del verso algo "incoherente", contrario a las reglas, y sin armonía. Menciona caídas en lo prosaico, transposiciones violentas, imágenes torcidas; en suma, las mismas cosas que habían de figurar siempre en las críticas hostiles dirigidas a la poesía llamada de "vanguardia" (págs. xiv-xviii).

Pero comparadas con las de la poesía futurista y cubista, las "faltas" de La gruta del silencio son bien poca cosa. En la versificación, Huidobro no va más allá del verso libre que había llamado en Pasando y pasando "una mezcla de ritmos armoniosa en su conjunto y perfectamente rimados en consonante o asonante". Esto significaba, en la práctica, que el poeta podía combinar consonante y asonante en un solo poema. Como resultado de este sistema son típicos dos cuartetos de "El poema para mi hija", el primero asonantado ("Arte-cisnegrande-sigue'), el segundo rimado ('escuálida-derroche-pálidanoche').

Para Huidobro la palabra 'ritmo' parece haber significado la sucesión de acentos dentro de los versos, el número de sílabas en los versos, y el número de versos en la estrofa. Como estrofa prefiere el cuarteto, que alterna a veces con coplas 
y grupos de cinco versos. El efecto total es de una regularidad tradicional, con pequeñas variaciones no muy frecuentes.

Varió con más frecuencia el número de sílabas por verso, pero aquí también las libertades aparecen muy de cuando en cuando. "La balada triste del largo camino" está en versos dodecasílabos con unos cuantos de once, trece y catorce sílabas; se nota el mismo proceso en poesías como "Idilio de la tarde y de la luna", y "Monotonía odiosa de las tardes nubladas". Rara vez rompe Huidobro con la tradición para presentar en un solo poema rima, estrofa y número de sílabas irregulares. Tal combinación resultó en la sensación de conversación familiar que da "La enfermita del engaño", cuadro de género muy distinto, por su tema, de las demás poesías introspectivas que dominan el libro:
Al pasar la señalan con el dedo
$Y$ las mujeres se hablan en voz baja
Es muy mala se dicen
$\mathrm{Y}$ repiten a coro "es muy mala".
$\mathrm{Y}$ pasa silenciosa intensamente pálida
La pobre muchacha
$\mathrm{Y}$ tiende la mano como una pordiosera.

En las poesías más acabadas de La gruta del silencio abandona Huidobro el vocabulario decorativo frecuente en Canciones en la noche, libro que rebosaba de comparaciones banales como ésta de "La muy amada": "Es así la muy amada/ una porcelana fina". La función de esta comparación es ilustrativa, y la idea de comparar a una mujer con algo tenido generalmente por raro y delicado, para dar a entender que ella también posee estas cualidades, tiene cierto parentesco con la convicción que entonces tenía Huidobro de que ciertos temas eran más poéticos que otros. Subrayamos estas perogrulladas porque el Huidobro creacionista de 1918 había rechazado estas prácticas tradicionales. Las habría comparado con la decoración de una casa, arguyendo que la función del poeta es como la del arquitecto, y que una imagen poética debe ser una creación autónoma sin función ilustrativa.

La tendencia hacia la imagen autónoma se encuentra ya en algunas poesías publicadas por Huidobro en 1914. En és- 
tas la función de la imagen es sin duda ilustrativa, pero la creación nueva que resulta empieza a hacer sombra a la comparación original. Una imagen de este tipo aparece como por descuido en un poema de Canciones en la noche, "Apoteosis", dedicado a Rubén Darío. El autor de Azul se eleva hacia el cielo, donde le oye cantar "un mitin de estrellas". No hay que insistir en el efecto de novedad, producido por 'mitin', definido por Larousse como "reunión pública de carácter político".

En algunas poesías de La gruta del silencio muestra Huidobro, por primera vez, un interés consciente en las posibilidades de este tipo de imagen. Ya citamos las observaciones que sobre la teoria de las correspondencias había hecho Huidobro en Pasando y pasando; su interés por la imagen fue algo natural, dado su descubrimiento de los simbolistas, cuyas teorías sobre la metáfora, sobre todo las del crítico Rémy de Gourmont, publicadas en el ensayo Le Problème du style, habían divulgado, entre grupos como los imaginistas angloamericanos y los futuristas, la creencia de que lo esencial de la actividad poética consistía en la creación de imágenes nuevas. 20 Más inmediato a Huidobro estaba el ejemplo de ciertos modernistas, sobre todo el de Julio Herrera y Reissig, quien había desarrollado, en sus sonetos sobre temas campestres, un tipo de poesía panteísta en donde la emoción del poeta quedaba identificada con el paisaje por medio de imágenes que personificaban al tiempo, al clima, y a la tierra misma. Claro que el proceso es viejo como la poesía, pero Huidobro supo aprovecharse especialmente de las experiencias de Herrera y Reissig.

"Amanecer poblano", de La gruta del silencio, lleva como epígrafe unos versos de un soneto de Los éxtasis de la montaña, de Herrera y Reissig. El poema comienza en un estilo metafórico típico de éste: "Por una gran pendiente se resbaló la noche/ y asoma la pestaña roja-azul de la aurora". Ya hemos dicho que en los sonetos de Herrera y Reissig la emoción se proyecta dentro del paisaje mediante la imagen; dice el

20 Rémy de Gourmont, Le Problème du style (París, 1902). Para la influencia del libro véase René Taupin, L'influence du symbolisme français sur la poésie américaine de 1910 à 1920 (París, 1929), págs. 109-112. 
uruguayo en "El Angelus": "a lo lejos/ el estruendo del río emociona la tarde". 21 Huidobro habla, en "Idilio de la tarde y de la luna", de La gruta del silencio, de un viento "enfermo de emoción/ cargado con adioses y lamentos/ que robara en alguna provinciana estación". El poema presenta una escena típica de Herrera y Reissig:

En la tarde que cae con suavidad de lana

Se alarga del camino la apacible oración,

$Y$ hay en el campo una santa paz virgiliana

De égloga evangélica y de buen corazón.

En un poema de Herrera y Reissig, "Claroscuro", "el crepúsculo ha puesto largos toques naranjos./ Amizclan una abuela paz de las Escrituras/ los vahos que trascienden a vacunos y cerdos/y palomas violetas salen como recuerdos/ de las viejas paredes arrugadas y oscuras".22 Imágenes de estilo parecido se encuentran en varias poesías de La gruta del silencio. "En monotonía odiosa de las tardes nubladas" hay una "tarde ojerosa con alma de cartujo"; en "Paisaje crepuscular", "persignan el cielo las negras golondrinas"; y en "La llanura de noche" se ve a lo lejos un "diálogo de luces".

Llama la atención la semejanza entre estas imágenes y las del grupo parisiense de Nord-Sud, en el que había de colaborar Huidobro. Este verso de "Monotonía odiosa de las tardes nubladas" recuerda de modo sorprendente el mundo de Pierre Reverdy: "Y pienso en una noche en que al volver una esquina/ me cayeron encima dos fuertes campanadas". Nótese cómo estas imágenes tienden a asumir cierta independencia, y cómo se va borrando la comparación original. Buen ejemplo del proceso son estos versos de "El libro silencioso": "Las palabras, reptiles en la gruta del alma,/ se retorcian de dolor y de espasmo./ Se enroscaban y huían a través de las páginas/ y ante el blanco silencio salmodiaban un canto".

Llegamos, en "La alcoba", a un grado más avanzado:

En la tarde que baja dolorosa

las ventanas se mueren de amor

21 Poesias completas (Buenos Aires, 1942), pág. 156.

22 Poesias completas, pág. 153. 
y como pulpos de mil ventosas

se beben toda la sangre del sol.

Las ventanas llameantes son los tentáculos abigarrados de una criatura viva que en una agonía de amor procura absorber la sangre del amado, o sean los rayos del sol. EI salto entre ventana y pulpo es más grande que en otras imágenes citadas hasta aquí, y el punto de partida, las ventanas, queda medio olvidado ante la presencia de la criatura nueva.

Aquí es evidente que la imagen va perdiendo la función ilustrativa. Esta tendencia hacia la imagen independiente, común a toda la poesía avanzada de la época, puede considerarse como el resultado lógico del solipsismo de los simbolistas. Si la realidad no tiene estructura fija fuera de la mente del poeta, bien puede éste llegar a la omnipotencia, a ser el "pequeño dios" de la frase de Huidobro. Pero esto existe sólo en germen en la obra juvenil de Huidobro que vamos estudiando. En el panteísmo de Las pagodas ocultas y La gruta del silencio no ha llegado a este extremo. Procura estar al diapasón con el mundo; no busca dominar y absorberlo. Sigue llamándose panteísta en el prólogo de Adán, largo poema publicado en Chile en 1916. Es cierto que ahora invoca también la autoridad de la ciencia, pero para él ciencia y panteísmo se reducen a una sola cosa. Las dos palabras significan amor por la naturaleza y comprensión intuitiva de ella. "Mi Adán", dice, "no es el Adán bíblico, aquel mono de barro al cual le infunden vida soplándole la nariz; es el Adán científico. Es el primero'de los seres que comprende la naturaleza, el primero en el cual despierta la inteligencia y fllorece la admiración. A este primer inteligente y comprensor le doy el nombre biblico de Adán" (pág. 21). Se ve que el Adán de Huidobro es una encarnación del poeta ideal. Narra el poema cómo despierta Adán al mundo de aguas, tierra, plantas, luz y tinieblas, su encuentro con Eva, el nacimiento de Caín y Abel, y la rivalidad entre éstos. Pero el énfasis está en el despertar de Adán y en lo que significa esto para el mundo. El libro está dedicado a Emerson, cuyo concepto idealista de la tarea del poeta repercute en la actitud de Huidobro. "El poeta", había dicho Emerson, "es el único sabio verdadero". Para 
Emerson es el poeta quien, para cada generación, reinterpreta en términos humanos los fenómenos de un mundo que no cesa de cambiar. "Pues cada período requiere una nueva confesión, otro modo de expresión, y el mundo parece que siempre espera su poeta". Cada generación de poetas tiene su forma característica, determinada por el pensamiento nuevo, "pues el poema no lo hacen los ritmos, sino el pensamiento creador del ritmo; un pensamiento tan apasionado, tan vivo, que como el espíritu de una planta o de un animal, tiene una arquitectura propia, adorna la naturaleza con una cosa nueva" (pág. 28).

Al arrogarse estas ideas avanzó Huidobro hacia el mundo de los cubistas. El mundo es pasivo, y el principio activo es la fuerza creadora del poeta. Tal es el papel del Adán de Huidobro. Antes de que se despierte Adán, la tierra, soñando en silencio, va "rodando sola en el vacío negro... como una sonámbula/ de sus solos sueños encantada". Vive desamparada, sin que mente alguna contemple su belleza. Esta sección titulada "La tierra" continúa en estos términos:

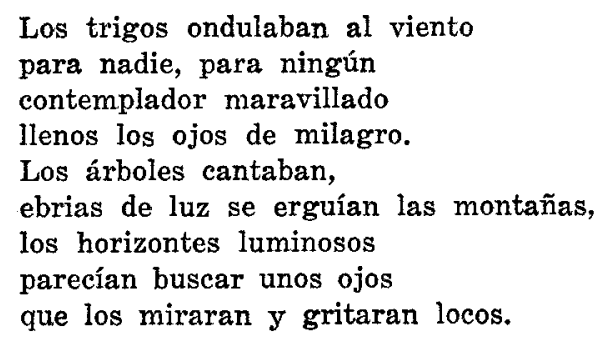

Sólo visto por ojos humanos, ojos de poeta, tiene el mundo vida plena. En la sección "La tierra" se hace mención, por primera vez en los escritos de Huidobro, del principio del ojo creador. Adán, "como quien despierta de un gran sueño/ atónito miraba el universo..."

$\mathrm{Y}$ con sus ojos nuevos sin nada de profundo

Adán iba adquiriendo las bellezas del mundo, iba adquiriendo formas su cerebro... 
Los cielos sonreían de blancura

y la Naturaleza limpia y pura

como recién nacida

se adivinaba al fin entera comprendida...

Al contemplar, incorpora en su ser los componentes del mundo:

y todo lo que miraban sus pupilas

su cerebro adquiría.

$\mathrm{Y}$ sentía crecer los árboles adentro, correr el agua por sus nervios,

brillar el sol en su cerebro.

Con los sentidos explora el mundo, y los espectáculos y sonidos que ofrece; los ordena con la inteligencia. Llegando a comprender esta belleza, "que se va apozando milagrosamente/ en el fondo de sus ojos/ llenos de campo verde", se va llenando de gratitud, y en reconocimiento lleva a la tierra a la consumación anhelada pronunciando la primera palabra:

La tierra santa de paz y de calma oyó en éxtasis la primera palabra y quiso acogerla para eternizarla.

He aquí lo esencial del poema, cosa que subraya el autor al terminar el "Epílogo" con esta invocación

Adản, primera

palabra que hirió el silencio de tierra

y se clavó en el horizonte

Iuminoso y enorme.

IOh Padre Adán, primera

mirada comprensora sobre la amada tierra!

Unica comprensión verdadera

porque todo lo miraba por vez primera

libre de adquisiciones anteriores

libre de herencias.

En el poder creador del ojo y de la voz del poeta Adán, encontramos anticipaciones innegables del Huidobro creacionista. Pero el estilo discursivo y didáctico del poema dista mucho del lirismo puro de Horizon carré; y en Adán, como 
en los otros libros de inspiración panteísta, el poeta canta el mundo de la naturaleza, no un mundo autónomo creado por él.

En resumidas cuentas, el joven Huidobro empezó su carrera como un romántico completo, obsesionado por la muerte y el más allá, quien aspiraba a hacer el papel de poetahéroe. Sus pretensiones de precursor, y los medios a que recurrió para establecerse como tal, le perjudicaron la carrera, fijando la atención del público y de los críticos en asuntos que en verdad no son de primera importancia para el estudio de su poesía. Si observamos la trayectoria de sus obras juveniles, vemos que gracias a la influencia de los modernistas y simbolistas evolucionó del primer romanticismo puro hacia un concepto de la forma poética y de la imagen aliado en muchos puntos con la doctrina del grupo cubista, al que se había de asociar en París. Por lo tanto, sería injusto insistir con algunos enemigos suyos en que su adhesión al grupo NordSud fué cuestión de imitación servil. Pero hay una distancia entre las anticipaciones del período chileno y el pleno creacionismo del período parisiense, distancia que no se explica sin la influencia de los poetas franceses. Afirmar con Huidobro que había inventado el creacionismo de una sola pieza antes de pasar a Europa sería inadmisible.

Pero hay más. Es evidente que este Huidobro discípulo de Emerson, quien cree que el poeta es el único sabio verdadero, quien se inicia en la literatura con el concepto del poeta como bardo, y quien sostiene con los "poetas malditos" la creencia en el poeta como mártir de su arte, tendrá que violentar sus más íntimas convicciones al abrazar el frío esteticismo del grupo cubista. Creemos que durante el período creacionista de Huidobro existe una tensión cada vez más intolerable entre estas convicciones y la doctrina a la que se había sometido, y esperamos tener la ocasión de demostrar que el grito de Altazor representa el estallido inevitable.

\author{
DAVID BARY, \\ Universidad de Wáshington.
}


OBRAS DE VICENTE HUIDOBRO CONSULTADAS PARA ESTE TEXTO

Ecas del alma (Santiago, 1910).

La gruta del silencio (Santiago, 1914).

Canciones en la noche (Santiago, 1941).

Pasando y pasando (Santiago, 1914).

Las pagodas ocultas (Santiago, 1914).

Adán (Santiago, 1916).

Horizon carré (Paris, 1917).

Es Espejo de aguat, "segunda edición" (Madrid, 1918).

Finis Britannia, une redoutable société secrète s'est dressée contre l'imperialisme anglats (París, 1923).

Manifestes (Paris, 1925).

Vientos contratios (Santiago, 1926).

Altazor (Madrid, 1931).

Antología, prólogo, selección, traducción y notas de Eduarcio Anguita (Santiago, 1945). 